\title{
DIE ANALOGIA ENTIS
}

Die vraag na die verhouding van die mens tot God bring ons in die middel van die problematiek van die wysbegeerte sowel as van die teologie van al die eeue, maar ' $n$ vraag wat in die moderne tyd hoe langer met hoe meer skerpte gestel word. Een van die eeue-oue begrippe, wat al sedert die vroeë Middeleeue geskiedenis gemaak het, is die begrip Analogia Entis. Só bekend is hierdie term dat teenswoordig - nou dat dit vaak weer en soms met besondere skerpheid gehanteer wordgewoonweg gespreek is van: D i e Analogia Entis.

Soos uit die woorde afgelei kan word, het ons hier te doen met $\mathrm{s} y \mathrm{n}$ en wel in algemene sin. Die,,woord e $\mathrm{s} s \mathrm{e}$ is buitegewoon veelsinnig en stel sowel ons onderskeidingsvermoë as ons geduld dikwels op die proef". ${ }^{1}$ ) Maar dan het ons ook te doen met a nalogi e, wat wys op 'n sekere ooreenkoms in die syn van twee of meer bestaande groothede. Verskil van interpretasie van die uitdrukking ontstaan juis deurdat daar op verskillende maniere nadruk gelê word op die ooreenkoms in syn. Die begrip word soms op allerlei terreine van die lewe toegepas, maar hoofsaaklik gaan dit tog op filosofiese sowel as teologiese gebied om die verwantskap of ooreenkoms tussen die Hoogste Wese of Opperwese en die wesens van allerlei aard en vorm, m.a.w. tussen God en mens of skepsel. Dis hierdie vergelyking waarvan daar by die gebruik van die term gewoonlik sprake is, wat so veel spanning en stryd.meegebring het in verband met hierdie figuur.

In óns tyd het daar weer 'n geweldige stryd ontbrand na aanleiding van die Analogia Entis en het hierdie begrip feitlik die strydpunt geword tussen Rooms-Katoliek en Protestants, as gevolg van 'n botsing op hierdie terrein tussen die Roomse dogmatikus Erich Przywara en die Switserse teoloog KarL Barth.

PRZYWARA het al etlike belangrike werke uitgegee, waarvan sommige in ander tale oorgesit is en waarin die begrip Analogia Entis 'n besondere belangrike plek inneem. Hy spreek selfs van 'n "Grundprinzip", die „Angelpunkt" en „Wegkreuzung", die een en die al van die Roomse dogmatiek en vanwaar alle stellings insake die verhouding van God en mens, Skepper en skepsel, natuur en genade uit ontwikkel moet word. BARTH aan die ander kant trek as protestantse christen met netso veel oortuiging teen die Analogia Entis op. In sy dogmatiek noem hy dit

1) W. J. Anlders: De Analogia Entis in het geding, Verslagen en Mededeelingen van de Koninklijke Academie van Wetenschappen, Amsterdam, 1937, bls. 31. 
selfs 'n uitvindsel van die Anti-Chris en is oortuig dat ' $n$ christen as gevolg daarvan alleen nooit rooms-katoliek kan en mag wees nie. Meer hoef ons nie aan te voer nie om die aktualiteit van ons onderwerp te bewys.

Soos gesê is die Analogia Entis veel ouer as hierdie teoloë van naam van ons tyd. Reeds die klassieke geleerdes het ruimte vir hierdie figuur gelaat. Hoewel Aristotrles die term Analogia Entis nooit gebruik het nie, kom die gedagte tog by hom voor. Dit bedoel wel nie gelykheid in wese nie, maar dan tog 'n sekere ooreenkoms. Analogia Entis veronderstel 'n sekere vergelykbaarheid, hoewel op die verskeidenheid nadruk gelê word. Selfs in die ideë-leer van Plato is 'n sekere vergelykbaarheid tussen die ideë nie uitgesluit gewees nie, sodat mens ook hier ruimte sou kan maak vir die Analogia Entis.

Analogia Entis is egter hoofsaaklik 'n term van die middeleeuse skolastiek en veral van Thomas Aguinus. Vir Thomas is die samehang van rede en geloof, van natuur en genade een van die vorms wat die Analogia Entis aanneem. Daar is baie soorte syn en almal is vergelykbaar met mekaar. Daar is 'n ens per se en daar is ook syn wat van iets anders afhang. God bestaan op Homself en alles anders het hul bestaan van Hom. So is Jahwe uit die Ou Testament die synde sondermeer. ThOMas wil dus aansluit by die Ou Testament, waar alles hul bestaan aan God ontleen. Hier val die onverbiddelike grens tussen die syn van God en die syn van alles wat buite Hom bestaan. Wat buite God is, het geen volstrekte bestaan nie. Die syn buite God is eindig en beperk, stoflik en verganklik. Die syn van God is onverganklik en onstoflik. Die Goddelike syn is die eintlike en normatiewe syn. God is in elk geval geen algemene syn, waar die res maar onderdeel van is nie. Tog het die skepsel 'n sekere deel (participatio) aan die Goddelike syn. Daar bestaan dus 'n sekere ooreenkoms tussen God en skepsel. Dieselfde terms op God en skepsel toegepas is hoewel nie sinoniem nie en ook nie homoniem nie, maar dan tog na eweredigheid (analogice). Ná Thomas het die Analogia Entis in die Roomse kerk en teologie 'n bekende figuur geword.

Die Hervorming het die figuur van die Analogia Entis nie verwerp nie, maar dit stil op die agtergrond gedruk. Mens het geen moeite gedoen om sig van die inhoud daarvan rekenskap te gee nie. Tog is dit vir ons duidelik dat die hele figuur in die gees van die Hervorming nie gepas het nie. Die Reformasie was daarby bo alles prakties en soteriologies ingestel en had geen tyd en sin vir bespiegelings oor allerlei probleme van skolastiese oorsprong nie. Veral by LUTHER is daar geen plek vir vergelyking nie, dus ook nie vir die Analogia Entis nie. Daar is by hom alleen plek vir die analogie van die geloof. By CALvYN is daar differensiasie van die skeppende syn en die baie vorms van geskape syn en sal daar moontlik plek gevind kan word vir 'n Analogia Entis.

In ons eie tyd het ons, soos ons reeds gesien het, die skerpe teenstelling tussen Przywara en Barth. By die eerste neem die Analogia 
Entis 'n sentrale plek in, deur die laaste word dit met 'n skerpe veroordeling verwerp as iets onchristeliks. So skerp is die stryd dat dit nog aanleiding kan gee tot 'n nuwe algemene heftige stryd tussen Rooms en Protestants.

Vir Przywara is die Analogia Entis van die grootste belang vir die filosofie sowel as vir die teologie. Hy sien samehang en vergelykbaarheid tussen alle syn en spreek van ,teilnehmendes Über-hin-aus-BezogenSein" Dit geld vir die syn sowel as vir die bewussyn, noëties sowel as ontologies, vir geloof en rede, natuur en genade. By Analogia Entis is volgens hom sprake van ' $n$ ens wat aan alles gemeen is en wat tegelyk só gedifferensiëer is, dat dit vir alle moontlike onderskeidings en proporsies plek maak. Vir proporsionaliteit is analogie die woord. Soos deur PRzYwara uitgewerk kan die Analogia Entis op alles en almal toegepas word in sover die syn aan alles gemeen is. Hierdie figuur is vir hom van so veel betekenis, omdat dit sig in soveel opsigte laat hanteer. Dit is as het ware die towersleutel wat alle deure oopsluit en stel mens instaat om tussen alles wat bestaan, verband te vind en te lê. Vir ons gevoel gaan Prlywara hier veel verder as Thomas, as hy inhoud gee aan die Analogia Entis. Maar hier kom ons later op terug.

Die ontmoeting tussen Przywara en Barth te Münster in 1929 het op 'n geweldige botsing uitgeloop en dit veral t.o.v. die Analogia Entis. Hier het hulle weë met 'n geweldige wending uitmekaar gedraai. Przywara het daar na die Analogia Entis tot sy eintlike gestalte uitgebou. BARTH het die teenoorgestelde gaan doen. Hy ontken beslis die moontlikheid van 'n algemene ontologie, die moontlikheid van 'n algemene syns-samehang, waaronder kerk en geloof ook opgeneem kan word. Uitgaande van die gansandersheid van Skepper en skepsel verwerp hy 'n ontologie en antropologie wat God en die geloof ook kan omvat, as onbestaanbaar. Die mens het volgens hom met God niks gemeen nie, nie in sy syn nie en ook nie in sy kennis nie. Daar is geen band tussen God en mens nie, behalwe die band van die geloof. Daar is geen kennis van God wat die mens van nature sou kan besit of verwerf nie. Dit sou anders meebring dat die relasie tussen God en mens tot iets natuurliks en vanselfsprekends gemaak word; dit sou alle middelaarskap soos wat dit deur die vleeswording van Christus tot stand gebring is, uitșluit of oorbodig maak. Die betrekking tussen God en mens word anders iets natuurliks en die godskennis natuurlike godskennis, wat nie meer genadegawe van God is nie en nie meer deur 'n onbegryplike godswonder $\mathrm{nl}$. deur die openbaring van God aan die mens meegedeel word nie. Elke natuurlike verwantskap, wat deur die Analogia Entis veronderstel word, moet BARTH beslis afwys en stel hy in die plek daarvan alleen die verwantskap van die geloof, die analogia fidei. Die relasie wat dan ooit tussen God en mens mag bestaan, is vrug van Gods genade 
alleen en bestaan in die slaan van ' $n$ brug oor ' $n$ anders onoorbrugbare kloof deur die openbaring, die openbaring wat die mens deur Gods genade alleen mag aanvaar in die geloof.

Ongelukkig kan ons nou die geweldige teenstelling tussen BarTH en Przywara nie verder uitwerk nie. Genoeg is in elk geval gesê om elke teoloog te laat sien die erns van die dinge waarom dit hier eintlik gaan en om hom te dwing om 'n studie te maak van die Analogia Entis aan die hand van hierdie twee teoloë van naam van ons tyd. In sy korte beoordeling gee die Groningse hoogleeraar W. J. AALDERS 'n duidelike kritiek op beide en wys op 'n tekort by Przywara sowel as by Barth. Aalders beroep hom op die inhoud, wat Thomas aan die Analogia Entis gegee het en vind dit onverenigbaar met die uiteensetting van PrzYwARA wat die Analogia Entis maak tot die een en die al van die christelike dogmatiek, sowel as met die uiteensetting van Barth wat die Analogie totaal verwerp. AAlders het groot waardering vir die motiewe van BARTH nl. om so die ,distansie", die gansandersheid tussen God en mens te bewaar, maar vind tog dat hy met sy analogia fidei, wat hy in die plek van die Analogia Entis wil stel en waardeur daar selfs 'n sekere „Gottförmigkeit" totstand kan kom by die mens, maar 'n haarbreed verskil van die Analogia Entis van die Roomse teologie . . A A AlDERs het per slot van rekening meer waardering vir die standpunt van Przywara, al verval hy in geweldige uiterstes, as vir die standpunt van BARTH

Dat beide Barth en Przywara met besondere heftigheid in verband met die Analogia Entis die swaard gekruis het, is o.i. goed te verstaan. Dit gaan werklik om iets wesenliks vir die christelike geloof. Dit gaan per slot van rekening om die al-oue vraag: hoe staan en bestaan die mens voor en teenoor God? Wat is die verhouding tussen Skepper en skepsel, God en mens, ewigheid en tyd, genade en natuur? Dis die antwoorde op hierdie prinsipiële vraag, wat die grondteenstelling tussen die Bybels- christelike- lewens- en wêreldskouing, en alles wat daarteenoor staan, uitmaak. Dis die tipiese' heidense gedagte van al die eeue, dat daar 'n gemeenskaplike synsgrondslag is tussen God en sy skepsel. En dat die Rooms-Katolisisme met sy leer oor die verhouding tussen kennis en geloof, natuur en genade, waar die laaste gesien word as liggende in die verlenging van die eerste, geweldig naby die heidense standpunt gekom het, is welbekend. In die beantwoording van hierdie verhoudingsvraag is dit, waar die weë van die christelike teologie en heidense filosofie uitmekaar gaan om mekaar nooit weer te raak nie. En dit is sy gevaarlike oriëntering aan die klassieke heidense filosofie wat Rome so vaak al gevoer het op 'n weg wat die christelike weg tog nie meet is nie. Die belangrike Bybels-christelike leerstelling, wat alle gemeenskap met die heidense lewens- en wêreldbeskouing afsny, is die „skepping uit niks", wat alle vorm van gemeenskaplikheid van syn en bestaan van en gevolglik vergelykbaarheid tussen God en wêreld onmoontlik maak. BARTH voer die stryd hier in belang van die ,absoluut kwalitatiewe onderskeid", die 
absolute diskontinuiteit, tussen God en mens, Skepper en skepsel, ewigheid en tyd, genade en natuur. En daarom is dit ook vanselfsprekend dat hy in botsing moes kom nie alleen met die Modernisme nie, maar ook met die konsekwent Roomse teoloog Erich Przywara.

Dis van betekenis dat Aalders daar op wys dat Przywara in sy uitwerking van. die Analogia Entis veel verder gaan as THомAs en dat dit nie anders kan uitloop nie as op 'n wêreldbeskouing, wat in hoofsaak panteisties is; dat Barth uitgaande van dieselfde opvatting van die Analogia Entis aan die een kant alle ontologiese gemeenskaplikheid verwerp en aan die ander kant iets anders in die plek daarvan stel, wat netso gevaarlik is en dat hy daar op wys dat hierdie twee teoloë in uiterstes verval het, omdat hulle hul aan die inhoud van die Analogia Entis, soos wat Thomas ARuinus dit ontwikkel het, nie gehou het nie. Nogtans moet ons hier die vraag stel op Przywara en saam met hom Karl Barth die lyne soos wat dit deur Thоmas gestel is, nie konsekwent deurgetrek het nie.

Volgens Tномаs veronderstel die Analogia Entis 'n sekere gemeenskaplike syn van God en wêreld en 'n sekere vergelykbaarheid, hoewel op die verskeidenheid tegelyk ook nadruk gelê word. Op sigself vind ons hierdie beskouing in stryd met die christelike leerstuk van die Creatio ex Nihilo. Dat Thomas groot nadruk gaan lê het op die verskeidenheid, dat waar daar by die skepsel sprake is van ens, God bekend moet staan as die ens per se en dat hierdeur daar 'n onverbiddelike grens val tussen die syn van God en die syn van alles wat buite Hom bestaan, maak die figuur van die Analogia Entis nie minder gevaarlik vir die christelike geloof nie. Die lyne wat van hieraf deurgetrek word, moet in die teologie van Przywara uitloop. Die verskil wat Thomas maak - soos die klassieke filosofie dit ook doen - tussen God en wêreld is nie absoluut nie en ook nie kwalitatief nie, maar relatief en kwantitatief. Dis hier geen verskil in wese nie, maar alleen in graad en daarom ook nie te handhaaf nie. Hierdie beskouing kan nie anders as op 'n monisme uitloop nie. Dan is Skepper en skepsel een en dieselfde syn, net in 'n ander gedaante gesien, soms is dit die Natura naturans en soms die natura naturata. Daarmee is die absolute dualisme van God en wêreld, die skeppende en die geskape wêreld onmoontlik gemaak en die creatio ex nihilo oorboord gegooi. Dis hierdie dualisme wat die sedelik-geestelike betrekking, wat met die vleeswording van Christus tot stand gebring is, vooronderstel, nie as iets wat vanselfsprekend is nie, maar as 'n onbegryplike wonder van Gods genade. Dis hierdie dualisme wat van openbaring openbaring maak en nie teofanie of Godverskyning of selfs 'n natuurlike ontplooiing van God in die natuur of skepping nie.

H. P. Wolmarans. 